Jurnal Selulosa Vol. 11 No. 1 Juni 2021 Hal. 1 - 8

\title{
Cellulose Microfibers from Salacca Midrib Fiber Isolated by the Mechanical Treatment
}

\author{
Venditias Yudha $^{1^{*}}$, Heru S. B. Rochardjo ${ }^{2}$, Ferriawan Yudhanto ${ }^{3}$, Satriawan D. Hariyanto ${ }^{1}$ \\ ${ }^{1}$ Department of Mechanical Engineering, Institut Sains dan Teknologi AKPRIND Yogyakarta \\ J1. Kalisahak 28, Yogyakarta, Indonesia \\ ${ }^{2}$ Department of Mechanical and Industrial Engineering, Universitas Gadjah Mada \\ Jl. Grafika No. 2, Yogyakarta, Indonesia \\ ${ }^{3}$ Department of Mechanical Technology, Universitas Muhammadiyah Yogyakarta \\ Jl. Brawijaya, Yogyakarta, Indonesia
}

Diterima : 21 April 2021, Revisi akhir : 21 Juni 2021, Disetujui terbit : 30 Juni 2021

\section{Isolasi Selulosa Mikrofiber dari Serat Pelepah Salak dengan Perlakuan Mekanik}

\begin{abstract}
Abstrak
Serat pelepah salak termasuk limbah alam yang melimpah di daerah Turi, Kabupaten Sleman, Daerah Istimewa Yogyakarta. Selulosa mikrofiber dari pelepah salak berhasil diisolasi dengan metode mekanis dan memiliki karakteristik fisik yang baik. Serat selulosa dengan ukuran mikro dapat memperkuat ikatan antara matriks dan serat karena area kontak yang luas. Metode untuk mengisolasi selulosa mikrofiber yaitu dengan pengadukan mekanis pada kecepatan putaran 5.000; 10.000; dan 15.000 rpm. Perlakuan pengadukan mekanis bertujuan untuk melakukan fibrilasi dan mengurangi ukuran serat karena efek putarannya yang tinggi. Karakterisasi dilakukan dengan XRD, FTIR, dan SEM. Hasil uji XRD menunjukkan bahwa pengadukan mekanis tidak merusak indeks kristalinitas selulosa mikrofiber. Indeks kristalinitas raw material yaitu 64,3\% naik menjadi 79,1\% untuk indeks kristalinitas selulosa mikrofiber. Identifikasi gugus fungsi menggunakan FTIR tidak menunjukkan perubahan senyawa selulosa akibat dari perlakuan mekanis. Pengamatan SEM menunjukkan bahwa selulosa mikrofiber yang diisolasi dari serat pelepah salak berukuran diameter 5-10 $\mu \mathrm{m}$ dengan panjang serat 100-300 $\mu \mathrm{m}$. Selulosa mikrofiber potensial digunakan sebagai penguat pada mikro komposit dan diekstrak menjadi material nanoselulosa.
\end{abstract}

Kata kunci: serat pelepah salak, selulosa mikrofiber, perlakuan mekanis

\begin{abstract}
Salacca midrib fibers are abundant natural waste in Turi, Sleman Regency, Daerah Istimewa Yogyakarta. Cellulose Microfibers from the salacca midrib fiber have been isolated by mechanical treatment and successfully have good physical characteristics. Cellulose fibers with micro sizes can strengthen the bond effect between the matrix and the fiber due to the vast contact area. The method for isolated cellulose microfibers by mechanical treatment with the rotation speed of 5,000; 10,000; and 15,000 rpm. Mechanical stirring treatment aims to undergo fibrillation and reduces fiber dimensions because of their high rotation. The characterization by XRD, FTIR, and SEM. The XRD results showed that the mechanical stirring treatment did not damage the crystallinity index of cellulose microfibers. The crystallinity index of the raw material is $64.3 \%$, increased to $79.1 \%$ for the microfiber cellulose crystallinity index. Identification of functional groups using FTIR did not show any changes in cellulose compounds resulting from mechanical treatment. Morphological observation of fibers by SEM shows that the diameter cellulose microfibers size obtained from salacca midrib fiber ranges from 5-10 $\mu \mathrm{m}$ with 100-300 $\mu \mathrm{m}$ in length. Cellulose microfibers have the potential to be used as reinforcement in micro composites and extracted into nanocellulose materials.
\end{abstract}

Keywords: salacca midrib fiber, cellulose microfibers, mechanical treatment 


\section{Introduction}

The natural fiber is one of Indonesia's abundant natural resources. Indonesia is located in a tropical area with high rainfall so that many types of plants could live and thrive. Salacca zalacca is a palm tree species that is one of the abundant natural potentials and has not been widely utilized. The part of the Salacca zalacca tree that could potentially be utilized is the midrib. Based on interviews with the local farming community in the Turi area, Sleman Regency, the midrib should be trimmed once a year as much as 6-8 stems (in 1 tree clump) to make it easier to harvest the snake fruit later. The midrib of Salacca zalacca trees have been trimmed into waste and only been utilized as compost by being buried in the ground to decompose. Natural fiber components include cellulose, hemicellulose, lignin, pectin, wax, and water-soluble substances (Li et al., 2007). In particular, cellulose is the most abundant source of renewable polymers available today. Therefore, it is considered an almost inexhaustible source of raw materials for the increasing demand for environmentally friendly and biocompatible products (Brinchi et al., 2013).

Many studies have been carried out to explore the potentials of biodegradable materials derived from nature to be applied as reinforcement in composite material, especially natural fibers. The natural fibers utilized for structural applications were researched and developed from micro to nanometer scale. The midrib fiber could be developed as reinforcement in composites material on the micro and nanometer-sized scale. Cellulose microfibers have been widely developed by researchers for their various method of isolation. One of various isolation methods for the production of cellulose microfibers by mechanical treatment such as by modified kitchen blender with a rotation speed of 21,000 rpm (Sukmawan et al, 2019; Saputri et al, 2018). Mechanical fibrillation utilizing a modified kitchen blender showed the results of fiber diameter size in the range of $20 \mathrm{~nm}$ to 20 $\mu \mathrm{m}$. A high-speed blender operated at a stirring speed of 37,000 rpm has succeeded in producing nanofiber sized with a uniform diameter of 15-20 nm (Uetani and Yano, 2011).

Cellulose microfiber (CMF) successfully isolated from various types of plants such as banana fiber (Ibrahim et al., 2010; Lismeri et al.,
2017), rubberwood (Lamaming et al., 2016), water hyacinth (Syafri et al., 2019), pomelo peel (Liu et al., 2018), soybean hulls (Ferrer et al., 2016), oil palm empty fruit bunch (Isroi and Cifriadi, 2018), Agave cantala (Rochardjo and Yudhanto., 2019), and cotton fiber (MartínezSanz et al., 2017). Each natural fiber has different characteristics, thus it is necessary to optimize the parameters to obtain cellulose microfibers with good characteristics for reinforcement. In this study, cellulose microfibers were isolated utilizing mechanical treatment as a candidate for reinforcement in the polymer matrix micro composite material. For further action, microfibers cellulose could be extracted into nanocellulose material. Mechanical treatment was utilized to accelerate the fiber fibrillation process due to its high-speed rotation effect. In addition, the variations of rotation speed and time are discussed for their effect on the crystallinity index of microcellulose fibers.

\section{Materials and Methods}

\section{Materials}

The raw material of salacca midrib fibers (SMF) obtained from the Salacca zalacca (Gaert.) Voss) plant in Turi, Sleman Regency. The salacca midrib fibers are cut in the range of 40-50 cm from the base. Sodium hydroxide ( $\geq 98 \%$ purity), pellets (anhydrous), was purchased from Sigma and Aldrich Chemical Co., Hydrogen peroxide (3\% purity), and distilled water were supplied by CV. Wahana Hilab Indonesia, Yogyakarta. All chemicals and reagents were of analytical grade.

\section{Isolation Method}

The purification process of cellulose from salacca midrib fibers was isolated by following the previous study procedure of Yudha et al (2019). Chemical composition refers to SNI 0492:2008 was determined two times by chlorite acid modification method and lignin for the raw fiber and treated fiber. Dried SMF was cut about $\pm 1 \mathrm{~cm}$ before being utilized in this research. Chemical treatment was carried out in two stages, alkalization and bleaching. In alkaline treatment, the fiber was immersed and stirred in $\mathrm{NaOH}$ solution with $2 \%$ wt. concentration at a temperature of $70^{\circ} \mathrm{C}$ for one hour. It was then 
proceeded with bleaching treatment immersed in hydrogen peroxide solution with $3 \%(\mathrm{v} / \mathrm{v})$ concentration at a temperature of $60^{\circ} \mathrm{C}, \mathrm{pH} 10$, for one hour. After each stage of treatment, the fibers were neutralized with $2000 \mathrm{~mL}$ of distilled water for every $20 \mathrm{~g}$ of fibers. Next step, then dried in the oven at a temperature of $70^{\circ} \mathrm{C}$ for one hour.

Mechanical treatment with a mechanical stirrer aims to reduce the size of cellulose to micrometer size. Purified cellulose fibers from the previous chemical treatment were dried and cut about $\pm 5 \mathrm{~mm}$. The ratio of fibers (gram) to distilled water $(\mathrm{mL})$ is 1:200. Figure 1 shows the mechanical stirrer instrument utilized for this research. The mechanical stirrer was operated with a final rotation of 450,000 times with threetime variations at different speeds and processing times (Table 1). The variation of rotation speed and time were studied for their effect on the crystallinity index. After the mechanical stirring process, the sample was neutralized with distilled water until the $\mathrm{pH}$ was neutral.

\section{Characterization}

SEM model JEOL-JSM 6410LA observed the surface and morphology of raw fiber, purified fiber, and cellulose microfiber. The SEM was operated

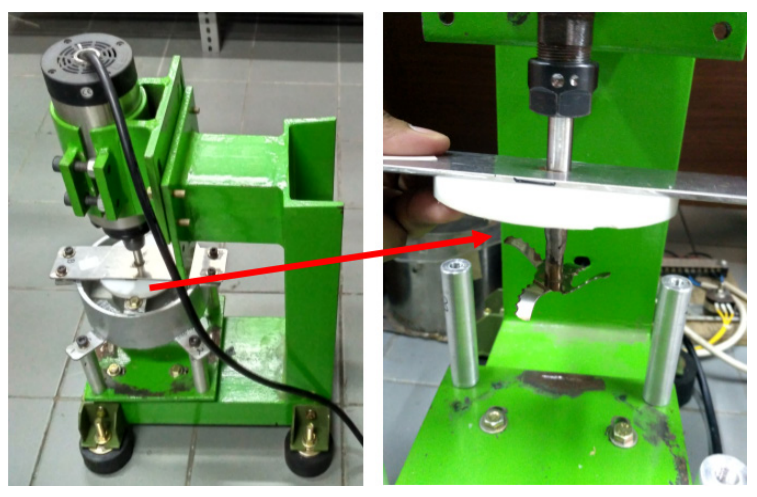

Figure 1. Mechanical stirrer instrument

Table 1. Parameter process for mechanical stirrer

\begin{tabular}{lccc}
\hline $\begin{array}{l}\text { Sample } \\
\text { designation }\end{array}$ & $\begin{array}{c}\text { Speed } \\
(\mathrm{rpm})\end{array}$ & $\begin{array}{c}\text { Time } \\
(\text { minutes })\end{array}$ & $\begin{array}{c}\text { Temp. } \\
\left({ }^{\circ} \mathrm{C}\right)\end{array}$ \\
\hline M15000 & 15,000 & 30 & 65 \\
M10000 & 10,000 & 45 & 55 \\
M5000 & 5,000 & 90 & 45 \\
\hline
\end{tabular}

utilizing an accelerating voltage of $3-15 \mathrm{kV}$ with the sample before being coated with a thin layer of Au. Fourier transform infrared (FTIR) aims to analyze the functional group of samples after and before the treatment, the FTIR model is Shimadzu operated in the range of $500-4000 \mathrm{~cm}^{-1}$. XRD instrument identified the structure of the fibers. XRD model is Rigaku which operated at the $\mathrm{CuK} \alpha$ radiation wavelength $(\lambda=1.5418 \AA)$ and the $2 \theta$ range was $5^{\circ}-40^{\circ}$. Calculation of crystallinity index using the Segal's equation (1) (Maheswari, et al, 2012):

$\mathrm{CrI}=\frac{\left(\mathrm{I}_{002}-\mathrm{I}_{\text {morph }}\right)}{\mathrm{I}_{002}} \times 100 \%$

where $I_{002}$ is the maximum peak intensity at $2 \theta=22^{\circ}$, represents the crystalline cellulose. The minimum peak intensity at $2 \theta=18^{\circ}$ indicated for the amorphous part (Pacaphol and Aht-Ong, 2017).

\section{Result and Discussion}

\section{Purification of Cellulose}

The first stage in this research is the purification process of cellulose on the salacca midrib fibers. Purification of cellulose was operated by chemical treatments called alkaline and bleaching. $\mathrm{NaOH}$ solution was utilized in the alkaline treatment to remove lignin (Chaker et al., 2013), pectin, and waxy substance. Higher cellulose content is better utilized for reinforcing resins because of the cellulose fiber's stiffness (Mwaikambo et al., 2002). $\mathrm{NaOH}$ has been utilized for alkaline treatment of the fibers with a concentration of 2 wt $\%$ at a temperature of $\pm 70^{\circ} \mathrm{C}$ for 60 minutes. The reaction of cellulose with $\mathrm{NaOH}$ is explained in equation (2) (Mwaikambo et al., 2002).

Cell $-\mathrm{OH}+\mathrm{NaOH}$ à Cell $-\mathrm{O}^{-} \mathrm{Na}^{+}+\mathrm{H}_{2} \mathrm{O}+$

(surface impurities)

The second step of purification treatment is bleaching. The bleaching treatment aims to remove hemicellulose and lignin residues that are still present in the fibers. The bleaching process referred to the previous research by Yudhanto et al. (2018), which used $3 \% \mathrm{H}_{2} \mathrm{O}_{2}$ at $60^{\circ} \mathrm{C}$ and $\mathrm{pH} 10$ for 60 minutes. The ratio of fiber (grams) and $\mathrm{H}_{2} \mathrm{O}_{2}$ solution $(\mathrm{mL})$ is 1:50. Figure 2 shows a different visualization of the fiber 


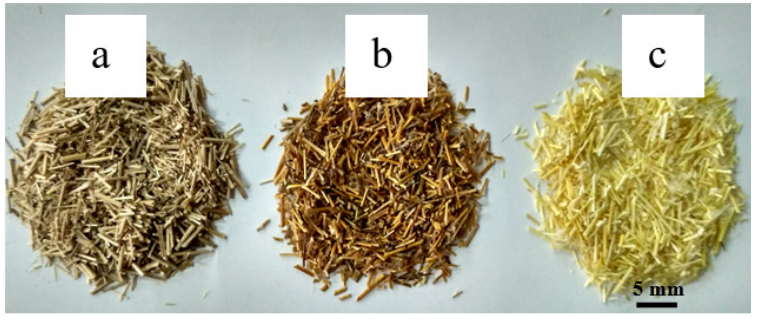

Figure 2. Photographs of a) raw fiber, b) alkalized fiber and c) bleached fiber

Table 2. Chemical composition of each cellulose purification

\begin{tabular}{lccc}
\hline Sample & $\begin{array}{c}\alpha \text {-cellulose } \\
(\%)\end{array}$ & $\begin{array}{c}\text { Hemi- } \\
\text { cellulose } \\
(\%)\end{array}$ & $\begin{array}{c}\text { Lignin } \\
(\%)\end{array}$ \\
\hline $\begin{array}{l}\text { Untreated } \\
\text { fiber }\end{array}$ & 47.30 & 31.85 & 22.70 \\
$\begin{array}{l}\text { Alkalized } \\
\text { fiber } \\
\text { Bleached } \\
\text { fiber }\end{array}$ & 56.74 & 19.30 & 22.21 \\
\hline
\end{tabular}

color during the purification process. After the bleaching process, the color of the fibers turned to a brighter yellowish color compared to the previous treatment of alkalization. Non-cellulosic material such as hemicellulose and lignin content were degraded during the purification process, as shown in Table 2.

\section{Morphological Anaysis}

The picture resulted from SEM observation showed that the fiber diameter has decreased after the bleaching process compared to the raw material (Figure 3a). Figure 3b showed the fibers diameter reduction and fibrillation in micrometer size after the bleaching treatment from a diameter of $450 \pm 3 \mu \mathrm{m}$ to a diameter of $350 \pm 2 \mu \mathrm{m}$.

The mechanical stirring reduces the fiber size to reach a micrometer and nanometer scale. The mechanical stirrer was used as a modification tool with a maximum rotation speed of 20,000 $\mathrm{rpm}$. The rotation speed of 5,000, 10,000, and $15,000 \mathrm{rpm}$ were varied to determine their effect on fibers' crystallinity after processing. The fibrillation of cellulose microfibers after processing by a mechanical stirring is shown in Figure 4.
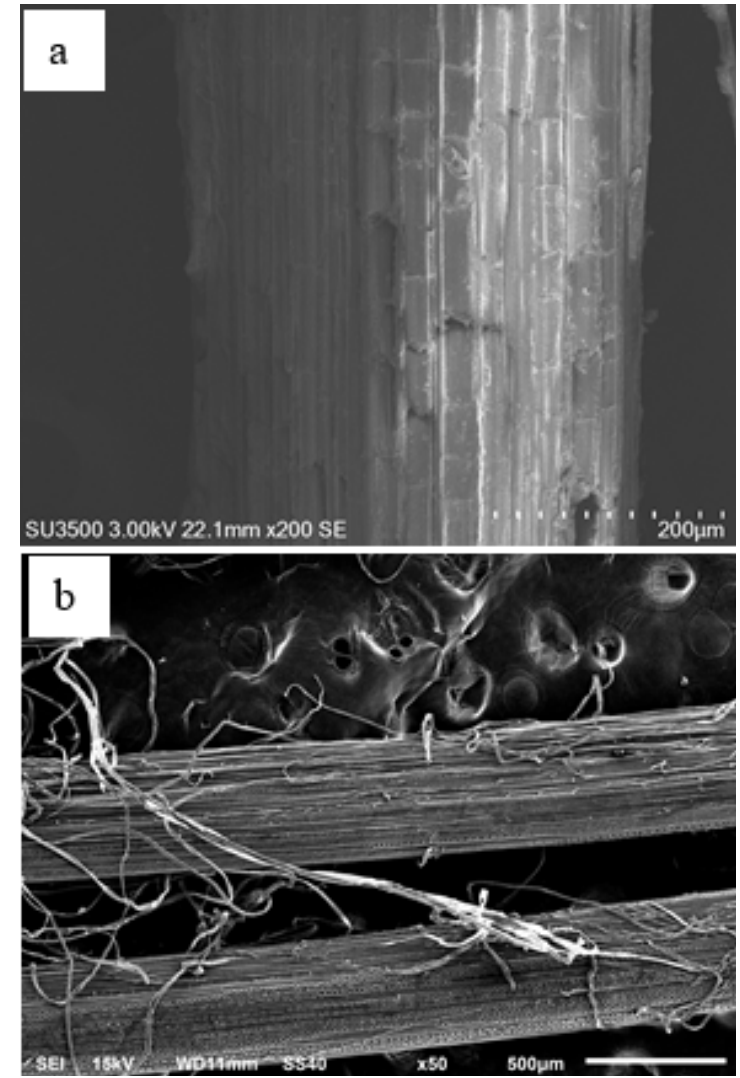

Figure 3. SEM micrograph of a) raw fiber and b) bleached fiber

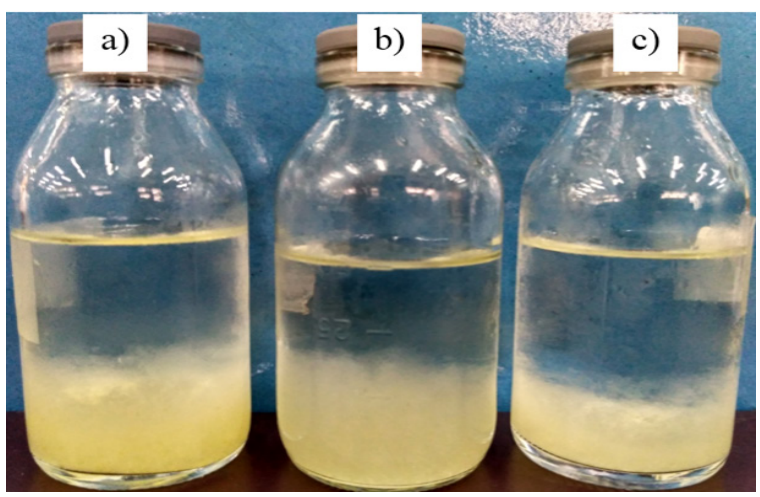

Figure 4. CMF after processing by mechanical stirring for: a) 5,000 , b) 10,000 and c) $15,000 \mathrm{rpm}$

Figure 5 shows the SEM images of CMF from the M5000 sample with the highest crystallinity index (CrI). The cellulose microfiber showed a broad polydispersity of 100-300 $\mu \mathrm{m}$ in length (Figure 5a), 5-10 $\mu \mathrm{m}$ in diameter (Figure 5b), and 10-25 in aspect ratio. These results are similar to previous research by Maheswari et al. (2012) on Coconut palm fiber leaf sheath with Chlorination and alkalization that produced cellulose microfiber with a diameter of $10-15 \mu \mathrm{m}$. 


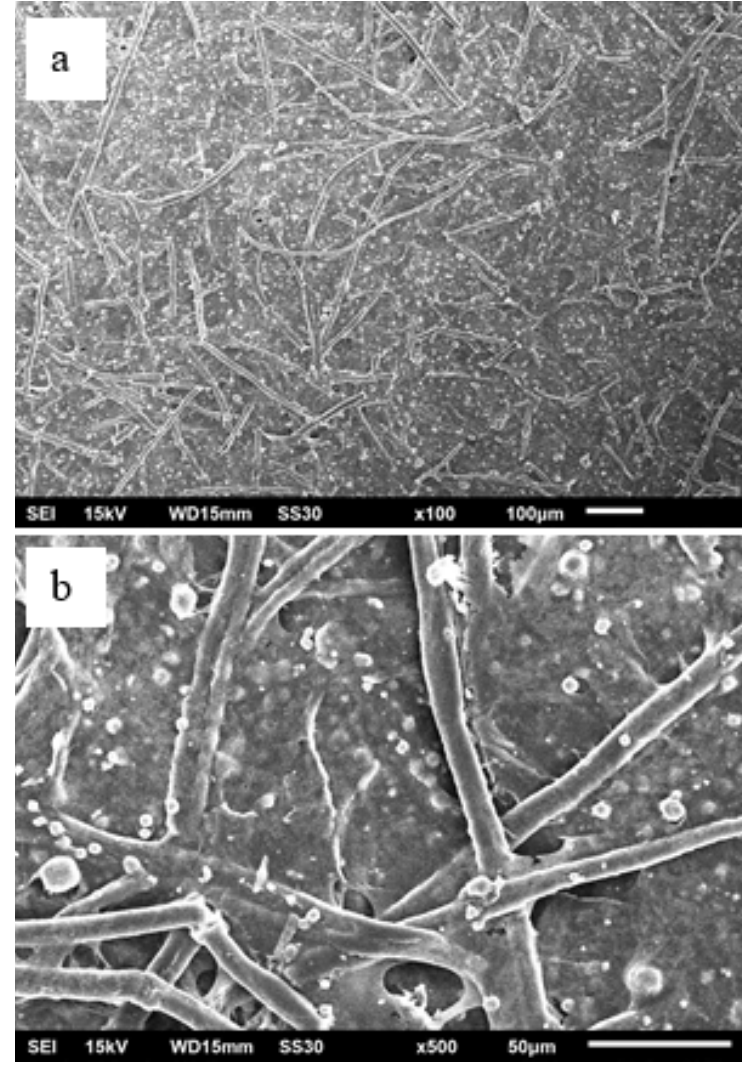

Figure 5. SEM image of CMF from the M5000 sample: a) 100x and b) 500x magnification

\section{XRD Analysis}

Figure 6 shown the XRD spectra of raw fiber, alkalized, and bleached fiber. All samples showed characteristic peaks of cellulosic fiber at $16.4^{\circ}, 22.5^{\circ}$, and $34.8^{\circ}$, corresponding to the crystallographic plane of (110), (002), (040), respectively (Maheswari et al., 2012). According to Mohammed et al. (2015), these peaks are characteristic of crystal structure for cellulose I on the XRD results of bamboo fibers. The pattern consists of crystalline and amorphous peaks, which are types of semicrystalline material (Tonoli et al., 2012). Hemicellulose and ligninbased in these observations, contribute to the amorphous material (Ferrer et al., 2016). These patterns Purification of cellulose consisted of alkaline and bleaching, due to non-cellulosic materials were degraded, each treatment showed an increase in the value of the crystallinity index. The crystallinity index of the raw fiber after the alkalization and bleaching process is presented in Table 3. The increase in the crystallinity index indicates that the amorphous area decreases after chemical treatment (Sonia and Dasan, 2013).

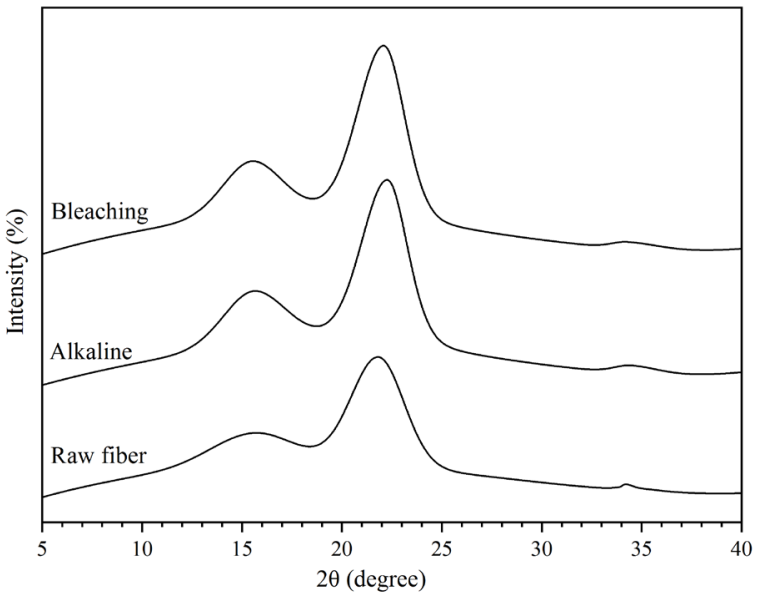

Figure 6. XRD pattern for the cellulose purification process

Table 3. Crystallinity index each step for cellulose purification

\begin{tabular}{lc}
\hline Sample & Crystallinity Index (\%) \\
\hline Untreated fiber & 64.3 \\
Alkalized fiber & 67.7 \\
Bleached fiber & 70.4 \\
\hline
\end{tabular}

Microfiber aggregation with hydrogen bonds in the fiber framework is affected by the hemicellulose content. The physic of hemicelluloses will fill the gaps between the cellulose microfibrils. They will act as a physical barrier that inhibits damage caused by the blade shear forces. (Chaker et al., 2013). XRD testing was carried out on all samples of the mechanical stirring process to analyze its effect on the fiber crystallinity index. Similar to the research results by Panthapulakkal and Sain (2012), the crystallinity index after mechanical treatment was higher than the previous treatment. The three patterns show crystal planes corresponding to 110 and 002 at the peaks of $16^{\circ}$ and $22^{\circ}$, respectively. The obtained crystallinity indexes were determined by Segal's equation. The crystallinity index of cellulose microfibers did not change substantially with stirring rotation speed and time. The crystallinity index values were estimated at $77.4 \%, 78.2 \%$, and $79.1 \%$ for the M15000, M10000, and M5000, respectively. The high-speed rotation at $15,000 \mathrm{rpm}$ for 30 minutes has affected the crystallinity index. The shear of the blade at high temperature $\left(65^{\circ} \mathrm{C}\right)$ on the cellulose affects the decreasing of CI. The 


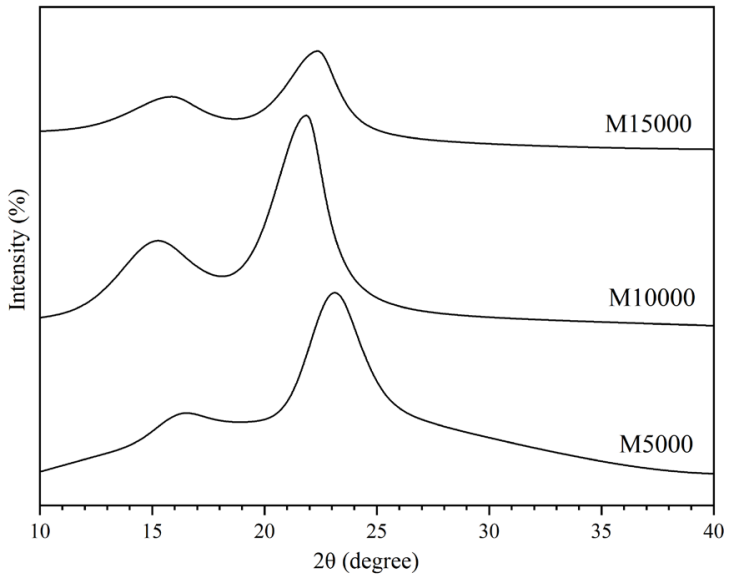

Figure 7. XRD pattern for the mechanical treatment

high temperature of cellulose can damage the crystalline structure due to high friction during the mechanical stirring process.

The low-speed rotation at 5,000 rpm for 90 minutes shows the highest crystallinity index. It does not affect $\mathrm{CI}$ because low friction results in a low temperature process $\left(45^{\circ} \mathrm{C}\right)$.

Thus, the chemical and mechanical treatments affect the crystallinity of cellulosic material (Ferrer et al., 2016). Figure 7 shows the X-ray diffractograms of all samples after mechanical treatment. Finally, we noted that to produce cellulose microfiber, the mechanical treatment with low-speed rotation (5,000 and 10,000 rpm) did not significantly affect the crystallinity index, which was confirmed from the analysis results of the XRD test. Similar to the research of Sofla et al., (2019), isolated cellulose from bagasse using a high-speed blender with medium speed and a long-time process (60 minutes) did not substantially affect the change in the crystallinity index of CNF materials. The ratio of cellulose and water used was 1:1,000, which aims to reduce the excessive friction between the cellulose and the blade and cause the temperature process to stabilize $\left(50-60^{\circ} \mathrm{C}\right)$.

\section{FTIR Analysis}

The spectroscopic approach is one of the methods used to characterize cellulosic fibers. FTIR spectroscopy was used to identify the effect of mechanical stirring on functional groups within the fibers. The FTIR spectra of raw fiber, bleached fiber, and cellulose microfibers are shown in Figure 8.

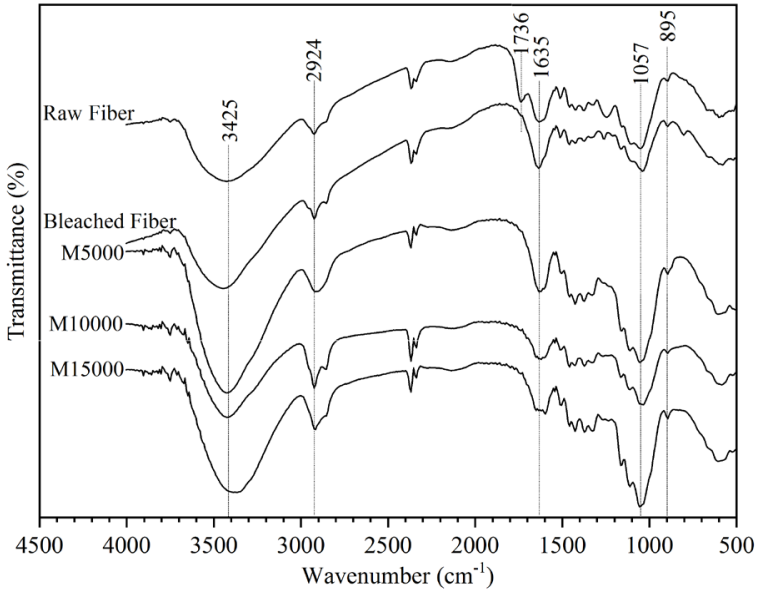

Figure 8. FTIR spectra of raw fiber, bleached fiber, and cellulose microfiber

All samples presented cellulose, hemicellulose, and lignin with their typical vibration bands. A strong absorption band at about $3,425 \mathrm{~cm}^{-1}$ is intermolecularly bonded hydroxyl $(\mathrm{O}-\mathrm{H})$ groups (Reddy et al., 2012). The broad bands at $2,924 \mathrm{~cm}^{-1}$ correspond to the $\mathrm{C}-\mathrm{H}$ stretching of methyl and methylene groups in cellulose, hemicellulose, and lignin (Maheswari et al., 2012). The peak at $1,736 \mathrm{~cm}^{-1}$ seen in the raw fiber disappeared upon alkaline treatment. This is because the carboxylic group was removed by an alkali treatment called the deesterification process (Mwaikambo et al., 2002). The peak at $1,635 \mathrm{~cm}^{-1}$ is the absorbed water in cellulose (Jankwoska et al., 2020). The peak at $1,504 \mathrm{~cm}^{-1}$ assigned to the $\mathrm{C}=\mathrm{C}$ stretch of the aromatic ring was taken as a lignin reference (Chaker et al., 2013). The stretching (C-O) and rocking $(\mathrm{C}-\mathrm{H})$ vibration of cellulose occurred at the absorbances of 1,057 and $895 \mathrm{~cm}^{-1}$ (Ferrer et al., 2016).

\section{Conclusion}

The chemical treatment succeeded in reducing the non-cellulose content of the salacca midrib fiber. The presence of non-cellulose content that is still attached to the cellulose can prevent damage to the crystal structure due to friction during the high-speed stirring process. The rotation speed during the mechanical stirring process affects the crystallinity index more than the operation time. The highest crystallinity index value was $79.09 \%$ for sample M5000. The average fiber diameter resulted from the isolation of cellulose 
microfibers by mechanical stirring ranged from $10-15 \mu \mathrm{m}$ with a length of $100-300 \mu \mathrm{m}$.

\section{References}

Brinchi, L., Cotana, F., Fortunati, E. dan Kenny, J. (2013). Production of nanocrystalline cellulose from lignocellulosic biomass: Technology and applications. Carbohydrate Polymers, Volume 94, p. 154- 169.

Chaker, A., Alila, S., Mutje', Pere., Vilar, M. R., Boufi, Sami. (2013). Key role of the hemicellulose content and the cell morphology on the nanofibrillation effectiveness of cellulose pulps. Cellulose, Volume 20, p. 2863-2875.

Ferrer, A., Salas, C. and Rojas, O. J. (2016). Physical, thermal, chemical and rheological characterization of cellulosic microfibrils and microparticles produced from soybean hulls. Industrial Crops and Products, 84, 337-343.

Ibrahim, M. M., Dufresne, A., El-Zawawy, W. K. and Agblevor, F. A. (2010). Banana fibers and microfibrils as lignocellulosic reinforcements in polymer composites. Carbohydrate polymers, 81(4), 811-819.

Isroi, I. and Cifriadi, A. (2018). Oxidation of Cellulose from Oil Palm Empty Fruit Bunch Using Hydrogen Peroxide in Alkaline Condition. Jurnal Selulosa, 8(02), 51-60.

Jankowska, I., Ławniczak, P., PogorzelecGlaser, K., Łapiński, A., Pankiewicz, R. and Tritt-Goc, J. (2020). Cellulose microfibers surface treated with imidazole as new proton conductors. Materials Chemistry and Physics, 239, 122056.

Lamaming, J., Sharudin, N. H., Hashim, R. and Sulaiman, O. (2016). Characterization of Cellulose Microfibers Isolated from Rubberwood (Hevea brasiliensis). International Journal on Advanced Science, Engineering and Information Technology, 6(2), 170-174.

Li, X., Tabii, L. G. dan Panigrahi, S. (2007). Chemical Treatments of Natural Fiber for Use in Natural Fiber-Reinforced Composite: A Review. Journal of Polymers and the Environment, pp. 25-33.

Liu, Y., Liu, A., Ibrahim, S. A., Yang, H. and Huang, W. (2018). Isolation and characterization of microcrystalline cellulose from pomelo peel. International journal of biological macromolecules, 111, 717-721.

Lismeri, L., Darni, Y. and Dimas, M. (2017). Isolasi Mikro fibril Selulosa Dengan Pretreatment Alkali Dari Limbah Batang Pisang. In prosiding seminar nasional baristand (pp. 40-45). Baristand Lampung.
Maheswari, C. U., Reddy, K. O., Muzenda, E., Guduri, B. R. and Rajulu, A. V. (2012). Extraction and characterization of cellulose microfibrils from agricultural residue-Cocos nucifera L. Biomass and bioenergy, 46, 555-563.

Martínez-Sanz, M., Pettolino, F., Flanagan, B., Gidley, M. J. and Gilbert, E. P. (2017). Structure of cellulose microfibrils in mature cotton fibres. Carbohydrate polymers, 175, 450-463.

Mohammed, L., Ansari, M. N., Pua, G., Jawaid, M. and Islam, M. S. (2015). A review on natural fiber reinforced polymer composite and its applications. International Journal of Polymer Science, 2015.

Mwaikambo, L. Y. and Ansell, M. P. (2002). Chemical modification of hemp, sisal, jute, and kapok fibers by alkalization. Journal of applied polymer science, 84(12), 2222-2234.

Pacaphol, K. and Aht-Ong, D. (2017). Preparation of hemp nanofibers from agricultural waste by mechanical defibrillation in water. Journal of Cleaner Production, 142, 1283-1295.

Panthapulakkal, S. and Sain, M. (2012). Preparation and characterization of cellulose nanofibril films from wood fibre and their thermoplastic polycarbonate composites. International Journal of Polymer Science, 2012.

Reddy, K. O., Shukla, M., Maheswari, C. U. and Rajulu, A. V. (2012). Mechanical and physical characterization of sodium hydroxide treated Borassus fruit fibers. Journal of forestry research, 23(4), 667-674.

Rochardjo, H. S. B., Jamasri, J. and Yudhanto, F. (2019). Extraction of natural fibers by highspeed blender to produce cellulose sheet composite. International Review of Mechanical Engineering, 13(12), 691-699.

Saputri, L. H., Sukmawan, R., Rochardjo, H. S. B. and Rochmadi, R. (2018, July). Isolasi Nano Selulosa dari Ampas Tebu dengan Proses Blending pada Berbagai Variasi Konsentrasi. In Seminar Nasional Teknik Kimia Kejuangan (p. 10).

Sofla, M. R. K., Batchelor, W., Kosinkova, J., Pepper, R., Brown, R. and Rainey, T. (2019). Cellulose nanofibres from bagasse using a high-speed blender and acetylation as a pretreatment. Cellulose, 26(8), 4799-4814.

Sonia, A. and Dasan, K. P. (2013). Chemical, morphology and thermal evaluation of cellulose microfibers obtained from Hibiscus sabdariffa. Carbohydrate polymers, 92(1), 668674.

Sukmawan, R., Saputri, L. H., Rochmadi, R. and Rochardjo, H. S. B. (2019). The effects of the blending condition on the morphology, crystallinity and thermal stability of cellulose microfibers obtained from bagasse. Indonesian Journal of Chemistry, 19(1), 166-175. 
Syafri, E., Wahono, S., Irwan, A., Asrofi, M., Sari, N. H. and Fudholi, A. (2019). Characterization and properties of cellulose microfibers from water hyacinth filled sago starch biocomposites. International journal of biological macromolecules, 137, 119-125.

Tonoli, G. H. D., Teixeira, E. M., Corrêa, A. C., Marconcini, J. M., Caixeta, L. A., Pereirada-Silva, M. A. and Mattoso, L. H. C. (2012). Cellulose micro/nanofibres from Eucalyptus kraft pulp: preparation and properties. Carbohydrate polymers, 89(1), 80-88.

Uetani, K. and Yano, H. (2011). Nanofibrillation of wood pulp using a high-speed blender. Biomacromolecules, 12(2), 348353.

Xie, J., Hse, C.-Y., Hoop, C. F. De., Hu, T., Qi, Jinqiu., Shupe, Todd F., (2016). Isolation and characterization of cellulose nanofibers from bamboo using microwave liquefaction combined with chemical treatment and ultrasonication. Carbohydrate Polymers, Volume 151, p. 725-734.
Yudha, V., Rochardjo, H. S. B., Jamasri, R. W., Yudhanto, F. and Darmanto, S. (2018, November). Isolation of cellulose from salacca midrib fibers by chemical treatments. In 3rd Annual Applied Science and Engineering Conference (AASEC 2018), IOP Conf. Series: Materials Science and Engineering.

Yudhanto, F., Jamasri and Rochardjo, H. S. B., (2018). Application of taguchi method for selection parameter bleaching treatments against mechanical and physical properties of agave cantala fiber. Banda Aceh, IOP Conf. Series: Materials Science and Engineering. 